\title{
The Effectiveness of the MIRS Approach in Improving Research Paper Writing Skill of Culinary Arts Vocational Student
}

\section{Endang Mulyatiningsih}

Departemen of Culinary Arts Vocational Education, Faculty of Engineering, Universitas Negeri Yogyakarta, mulyati@uny.ac.id

\section{Sugiyono}

Faculty of Engineering, Universitas Negeri Yogyakarta, sugiyono@uny.ac.id

Research paper writing is an essential factor and one of the challenging tasks for students. This study aims to examine the effectiveness of the MIRS (Motivation, Inspiration, Realization, and Solution) approach students' capability to write the research papers. This study employed the quasi-experimental design, specifically using equivalent time series method. The subjects of the study were the students of the Culinary Arts of Vocational Education. The research subjects were 154 students. The data were collected using authentic assessment with oral examination on pre-proposal, a paper and pencil (PP) test on research methodology, and a performance test on research proposal seminar. Statistical description and independent sample t-test are used to analyze the results. The results show that the number of the students of treatment group who were able to write innovative research papers increased. The control group's average score of the research paper writing is lower than that of the treatment group. Hypothesis shows that there is difference result between PP testing and oral testing. The alpha score obtains 0,003 for PP testing and 0,002 for oral testing. It can be concluded that MIRS approach is effective for improving writing skill capability.

Keywords: research paper, writing skill, motivation approach, MIRS, arts, students

\section{INTRODUCTION}

Course completion time has drawn special attention of Yogyakarta State University (YSU) authority. Undergraduate students of YSU usually take around four years for finishing their study. In fact, most students need more than in the time duration to finish its. Due to of this, the university regulates that students have to finish their study for maximum seven years. It is reported by the rector that the longest time duration of YSU's students to graduate their study is seven years and the fastest one is 3.3 years (The Rector's Annual Report in the $52^{\text {nd }}$ Anniversary of YSU). It is said that the average

Citation: Mulyatiningsih, E., \& Sugiyono. (2020). The Effectiveness of the MIRS Approach in Improving Research Paper Writing Skill of Culinary Arts Vocational Student. International Journal of Instruction, 13(1), 653-668. https://doi.org/10.29333/iji.2020.13142a 
of the time duration of YSU's students is 4.65 years. If students are persistent and work hard, they will graduate faster. One of the requirements to complete the course, it is heavily dependent on how fast students are able to write research papers.

Research Methodology in Education course aims to prepare students becoming good writer on the research papers (RP). In fact, they find it hard to write research papers because of their limited insights on educational research, lacking of understanding of potential research problems, and lacking of an academic writing skill. Several steps should be taken if they want to write a good research paper. They have to read a lot of scientific journals, reference books relevant to their field of studies, train their critical thinking, and learn to write honestly. In addition to these, they also have a good motivation and passion to reach the goals. In 2012, Payne stated that writing motivation can be indicated by the several low response questions, subjects with many writing assignments, writing essay and paper, and writing online discussion.

In fact, many students of Culinary Arts of Vocational Education program prefer to the technical skills (cooking skills) rather than skills in reading and writing academic papers. Writing skill of the research paper needs intrapersonal intelligence and linguistic-verbal intelligence, whereas cooking skill needs bodily-kinaesthetic intelligence. Gardner (2011) and Armstrong (2018) studied that a group of students usually can have strong talent at the specific knowledge, yet it usually has the weakness on the certain subject. In this condition, lecturers have to deliver the material courses to his/her student appropriately. Several difficulties of the research paper facing by students should be reduced or eliminated using appropriate strategy. According to McNiff (1998), the writing difficulties are related to the lacking of the students creativity, student writing motivation, student self-capability, and the time use to rehearsal.

The lecturers in charge of the Research Methodology are also expected to inspire and motivate students to formulate research problems and guide the students who are having trouble with writing their research papers. The lecturers should have a lot of research experience to be able to provide solutions that address each student's ability. Many efforts have been made aiming to help students develop fluency in writing research papers. However, the end results are tightly dependent on each individual's ability and willingness to learn. To overcome these problems, several methods were attempted to practice in Research Methodology both reading and writing skills. One of those method is by observing students' characteristics, including motivation, inspiration, realization and solution, namely MIRS approach. The MIRS approach emphasize on students' enthusiastic how to write research paper.

This study aims to examine: (1) students' capabilities to write research papers which are assessed based on: (a) the title quality of the research papers, (b) the research methods and topics chosen by students, (c) students' comprehension level on research method and theories; and (2) the effectiveness of the MIRS approach to improve students' capabilities to write research paper. The use of MIRS approach in this study is considered because this approach provides motivation for students to write, inspiration 
for helping their research paper titles formulation, encouragement for them to realize or express their ideas into research proposals, and solutions when they face any problems.

\section{LITERATUR REVIEW}

Sturm and Rankin (2002) stated that composing is an advanced academic task within educational settings and parts of the students' difficulties in writing are related to difficulties in applying various cognitive strategies. Therefore, various methods for teaching academic writing have been developed. Negari (2011) applied an instructional strategy and EFL learner's writing skill. The results of the analysis of covariance revealed that the instruction of concept mapping strategy had a positive effect on EFL learners' writing skill. The students in the experimental group achieved the instruction for the concept mapping strategy.

Blythe and Sweet identified six approaches to the teaching of academic writing i,e. the atelier approach, the great works approach, the inspiration approach, the techniques approach, the workshop approach, and the feminist approach. Those approaches can be elaborated as follows. Firstly, the atelier was adapted in writing processes. This method occasionally occurred with the master being a great author, a tutor/professor, or even an editor. Secondly, the great works approach is an extension of the Altelier. It derived from the ancient concept of imitatio, or imitation. This method originally demanded students to study the techniques, forms, and content of the ancient classical writers and copy them. Thirdly, the inspiration approach emphasizes copying or learning from others then creating one's own work. Fourthly, the techniques approach emphasizes the instructor who utilizes excerpts from great and minor work and writers to illustrate technical concepts. Fifthly, the workshop approach is a collection of apprentices led by a single master. The workshop functions as a test market for beginner writers. The workshop is a doorway for the beginners to get criticisms and motivation to write because of the deadlines that are imposed. The final approach is the feminist, feminist teachers distance themselves from authoritarian approaches, asking students, especially female students, to discover what they truly feel and to adopt their own voice. The Feminist Approach seemingly doubts the efficacy of the Atelier and Great Works approaches since both have evolved from a masculine social structure (Blythe \& Sweet, 2008)

Adapted by those six approaches, this research classroom applies MIRS approach to teach academic writing. The inspiration approach was adapted to widen students' ideas in choosing topics and constructing titles for their research papers; the Techniques Approach was adapted to teach how to write scientific papers correctly; and the workshop approach was adapted to help students express their ideas into research proposals. To find research problems and formulate research papers' titles, students need realistic ideas. Lecturers have to provide inspirations that enable students to have ideas for their research paper titles which are relevant to their field of studies

Writing is one of the most difficult skills that requires the mastery of cognitive and sociocultural competencies. De Larios, et.al. (2006) identify five behaviours that writers need to acquire: (1) the ability to manage complex mental representations, (2) the ability 
to construct rhetorical and organizational goals and hold them in mind while writing, (3) the efficient use of problem-solving procedures in order to formulate their texts, (4) the ability to distinguish between editing and revision as two different operations distributed in different stages of the writing process, and (5) the adoption of a flexible attitude toward the use of rhetorical devices. The lecturer's encouragement (motivation) is expected to help students find their focus to write research papers amidst their busy academic schedules. Focus and concentration are important for students to keep their ideas flowing when writing research papers. Intrinsic motivation gives energy and direction to behaviour in the absence of reward and punishments. It affects learners to choose a task, get excited about it, and persist until they master it (Tombari \& Borich, 1999).

Creative writing is unique to every individual; it should be parochial. Creative writing requires one to be a good reader; students should be guided to read a wider range of topics other than their current interests (Winterson, 2012). Nevin Akkaya suggests that teachers should emphasize that creative writing develops the imagination, helps uncover abilities, increases self-confidence, develops writing ability, encourages one to think and move beyond clichés etc" (Akkaya, 2014). Students are able to express their ideas if they have knowledge and knowledge can be obtained from reading. Therefore, to be able to write a good paper, one is required to read a lot.

After perusing several strategies to teach academic writing, MIRS approach is decided to be used in writing research paper in classroom. Motivation to write is given to students to prompt them to set their personal targets and achieve them. The MIRS approach also helps students find inspiration for their writings so that they will be filled with creative ideas to formulate research problems. Their creative ideas are then realized by writing research proposals and they are facillitated with workshop on proposal writing techniques. If they face problems in writing research proposals, the lecturers should help them finding solution. Akkaya (2014) studied same experiences, then three strategies are applied to overcome student problems in developing the ability to write scientific papers. Those three strategies can be listed as follows. (1) For poor reading problems, the lecturers should assign students to write the readings that they do not cover in class, and to ask students to write expressively in response to texts (reading logs, summary/response notebooks). (2) For failure to reconstruct arguments of what students read, the lecturers should assign summary writing and have students make outlines, flowcharts, or diagrams of articles. (3) for failure to adapt to different kinds of discourse, the lecturers should explain their own reading process: when they skim, when they read carefully, when they study a text in detail, and so forth; explain how their own reading process varies when they encounter different genres of text, how to read a textbook versus a primary source, how to read a scientific paper, how to read a poem; and so forth (Dorothy \& Ferguson, 2011).

The way to teach writing of scientific papers is reviewed by many researchers. Smedt and Keer found no significant differences between peer-assisted and individual writing practices. The peer assisted writing in education is more effective. Step-by-step learning is carried out with the following steps: (1) the teacher mentions the goals and motivates 
students to learn, (2) the teacher gives examples and writing strategies, (3) students practice writing and the teacher provides feedback; (4) the teacher concludes the lesson (Smedt \& Keer, 2018). People tend to produce their best work when they enjoy what they are doing.

Research paper writing remains an uninteresting and unexciting activity for many university students (Bernardo, 2010). They may not have realized its indispensable value in their respective disciplines and target workplaces. Hence, teachers must provide more enticing and more motivating classroom-based writing tasks to spur students' interest in producing varied academic texts. It is in this light that this paper proposes a number of "fun tasks" that teachers may use as their pre-writing tasks, lesson spring boards or enrichment exercises when they teach the rudiments of academic writing or research paper production. The use of these "fun tasks" is based on the premise that cultivating students' interest in research largely depends on the creativity of the teachers and the appeal of classroom activities and that learning could better take place when students are motivated and when they enjoy the learning process at the same time. Bernardo (2010) designs the following fun task to improve students' writing skill: (1) Library Hunt, is an interesting way for students to get familiar with the library; (2) Solve that Gobbledygoo:is an exciting way to teach the concept of conciseness and brevity reckoned to be an important writing skill; (3) Nosebleed: the exercise likewise teaches the students to write not to impress but to express ideas by dissuading them from using high-sounding words; (4) Survey Says: this activity provides students with initial experience of gathering pertinent data; through this exercise, the students are also introduced to simple data analysis; (5) Go APA Online, is an interesting web-based activity that allows students to use online learning resources and teaches the students how to document references and write in-text citations using the APA style (Bernardo, 2010).

Every lecturer has a different teaching method. Lengeling and Malarcher created games to improve students' writing skills. They argue that games will benefit students in the following aspects: (1) in the affective aspect, games increase motivation, and provide fun learning experience; (2) in the cognitive aspect, games provide reinforcements and opportunities for review and extension tasks; (3) in the adaptability aspect, games provide easy adjustment for age, level, and interests, involve all four skills, and require minimum preparation after development (Lengeling \& Malarcher, C, 1997). Caldwell teaches academic writing with the following conventional steps: (1) drawing the students' attention to the necessity of redeveloping the basics of their writing; (2) involving them in a number of practical writing exercises; (3) giving them feedback; (3) dedicating the first fifteen minutes of each period for quick revision (Caldwell, 2011).

Aside from using certain teaching method, innovation in teaching academic writing can also be done by utilizing digital technologies. Arlina \& Melor stated that mobile learning can be integrated into academic writing by using it with several writing approaches which complement the pedagogical advantages in mobile devices. Perhaps the future will bring electronic Ateliers in the form of online tutors or computer programs that instruct new writers one-on-one (Arlina \& Melor, 2015). 
Writing capability of the research paper cannot be assessed using objective test. Hence, new development instrument should be used as an alternative or authentic assessment. The authentic assessment is the instrument to measure students' performance comprehensively. This method is also used for measuring theoretical methodology and feasibility of the writing research paper. Due to of this, the authentic assessment has been used by many scholars at the project learning based. This method is measured whether the students can create a project with their chosen topic, prepare a report, and present their products to evaluators (DiMartino \& Castaneda, 2007). According to Eby (1998), authentic assessment is a task that mostly enables students to use their cognitive processes besides showing them what they have learn and what they do (Eby, 1998). Authentic assessment, or sometimes also called performance assessment, appropriate assessment, alternative assessment, or direct assessment, contains such techniques as written texts, portfolios, checklists, teacher observations, and group projects (Olfos \& Zulantay, 2007).

\section{METHOD}

\section{Research Design}

This study employed the quasi-experimental design specifically the equivalent time series with the the control group design (Neuman, 2011). The treatment was given continuously in accordance with research paper writing steps starting from formulating a title, writing a research paper, and research paper seminar. The quasi-experiment research design can be seen in Table 1 .

Table 1

Research Design

\begin{tabular}{|c|c|c|c|c|c|c|c|c|c|c|}
\hline Variation & Year & M & I & & $\mathrm{R}$ & & $\mathrm{S}$ & \multicolumn{3}{|c|}{$\mathrm{S}$} \\
\hline Control & 2017 & $\mathrm{X}$ & $\mathrm{X}$ & O1 & $\mathrm{X}$ & $\mathrm{O} 2$ & $\mathrm{X}$ & $\mathrm{O} 3$ & $\mathrm{X}$ & $\mathrm{O} 4$ \\
\hline Experimental & 2018 & $\mathrm{X} 1$ & $\mathrm{X} 2$ & O1 & X3 & $\mathrm{O} 2$ & $\mathrm{X} 4$ & $\mathrm{O} 3$ & $\mathrm{X5}$ & $\mathrm{O} 4$ \\
\hline \multicolumn{11}{|c|}{ where the variables written in Table 1 can be listed as follows. } \\
\hline \multicolumn{6}{|c|}{$\mathrm{O} 1=$ Title grade (creativity, theme, and method) } & \multicolumn{2}{|c|}{$\mathrm{X} 1=$ treatment 1} & \multicolumn{3}{|c|}{$\mathrm{M}=$ motivation } \\
\hline \multicolumn{6}{|c|}{$\mathrm{O} 2=$ Grade of oral examination on pre-research paper } & \multicolumn{2}{|c|}{$\mathrm{X} 2=$ treatment 2} & \multicolumn{3}{|c|}{$\mathrm{I}=$ inspiration } \\
\hline \multicolumn{6}{|c|}{$\mathrm{O} 3=$ Grade of research methodology comprehension } & \multicolumn{2}{|c|}{$\mathrm{X} 3=$ treatment 3} & \multicolumn{3}{|c|}{$\mathrm{R}=$ realisation } \\
\hline \multicolumn{6}{|c|}{$\mathrm{O} 4=$ Grade of research paper presentation } & \multicolumn{2}{|c|}{$\mathrm{X} 4=$ treatment 4} & \multicolumn{3}{|c|}{$\mathrm{S}=$ early solution } \\
\hline \multicolumn{6}{|c|}{$\mathrm{X}=$ Course grade (conventional) } & \multicolumn{2}{|c|}{$\mathrm{X} 5=$ treatment 5} & \multicolumn{3}{|c|}{$\mathrm{S}=$ last solution } \\
\hline
\end{tabular}

\section{Research Process}

The research was conducted in the even semester of the academic years 2017 and 2018. The location of this studied was at the Department of the Culinary Arts of Vocational Education, Faculty of Engineering, Yogyakarta State University. A set of treatments was given to sample students for one semester for 16 weeks. The research was conducted according to the following time shown in Table 2. 
Table 2

Research Procedure

\begin{tabular}{ll}
\hline \multicolumn{1}{c}{ Activity } & Weekly meeting \\
\hline 1. Motivation \& Inspiration & $1-4$ \\
2. Map of Research Titles & $5-6$ \\
3. Realization & $7-9$ \\
4. Solution in oral exam & $10-13$ \\
5. Theory Examination & 14 \\
6. Performance test & $15-16$ \\
\hline
\end{tabular}

\section{Sample}

The sample of the study were established using the simple random sampling technique. The control group consisted of the students taking Educational Research Methodology course in the even semester of 2017 without the MIRS approach. Meanwhile, the treatment group consisted of the students taught in the even semester in 2018 employs the MIRS approach. The framework of research sample is presented in Table 3.

Table 3

Framework of Research Sample

\begin{tabular}{llllc} 
& \multicolumn{2}{l}{ The control group (2017) } & \multicolumn{2}{c}{ The treatment group (2018) } \\
\hline Class A & $\mathrm{N}$ & $\mathrm{N}$ & $\mathrm{N}$ & $\mathrm{N}$ \\
Class D & 49 & 45 & 38 & 37 \\
Total & 38 & 35 & 42 & 37 \\
\hline
\end{tabular}

\section{Data Collection Tool}

The data were collected using the documentation of research paper. The research paper was assessed using several methods, including oral examination, rubric of the students' performance, and constructed response test. The data collection was conducted through the following steps as follows. 1). The data of students' performance are assessed based on: (a) the research titles, (b) the research methods, and (c) the topics chosen by students. 2). Students' comprehension level on research method is measured using paper and pencil (PP) test formed constructed response (CR). 3). Oral examination is used to examine the feasibility of the pre/pra-research papers. 4). The students' performance of the research presentation is assessed using the rubric.

\section{Data Analysis}

The collected data were analysed using descriptive statistics and independent sample ttest. The descriptive statistic is used to generally describe the writing title creativity, the research topic, and the research method used. Independent sample t-test is used to examine the effectiveness of the MIRS approaches in term of the writing students' capability improvement. The experimental result is effective if the group of the treatment obtains higher average of the writing capability. In this condition, the alternative hypothesis (Ha) is proven or accepted significantly. The input data of the independent sample t-test is resulted from the assessments, including oral examination, 
constructed response $(\mathrm{CR})$, and the presentation of the research paper between the treatment and control classrooms.

\section{FINDINGS}

The results of the research paper analysis are classified into 4 parts, namely: (1) the research topics and the research methods; (2) pre-research paper writing skill; (3) comprehension the theory of research methodology and (4) presentation of the research plan performance

\section{Research Topic Mapping}

The research topic of this paper is mapped two categories, including teaching and learning subject and culinary subject. The teaching and learning subject is composed into five topics, including vocational teacher, character, learning strategies, learning media, learning outcomes. The culinary subject is composed into four topics, including culinary business, culinary marketing, culinary art, and culinary nutrition. The research topic is presented in Table 4.

Table 4

The Research Paper Topics

\begin{tabular}{llllll}
\hline \multirow{2}{*}{ No } & \multirow{2}{*}{ Topics } & \multicolumn{2}{c}{ The Control Group } & \multicolumn{2}{c}{ The Treatment Group } \\
\cline { 2 - 5 } & & $\mathrm{N}$ & $\%$ & $\mathrm{n}$ & $\%$ \\
\hline \multirow{2}{*}{1} & Teaching and learning & 8 & 10 & 13 & 17.57 \\
\cline { 2 - 5 } & a. Vocational teacher & 0 & 0 & 2 & 2.7 \\
& b. Character & 12 & 15 & 1 & 1.35 \\
& c. Learning strategies & 18 & 22.5 & 19 & 25.68 \\
& d. Learning media & 2 & 2.5 & 2 & 2.7 \\
\hline \multirow{2}{*}{ e. Learning outcomes } & Culinary & & 0 & & 0.00 \\
\cline { 2 - 5 } & a. Culinary business & & 0 & 3 & 4.05 \\
& b. Culinary marketing & 21 & 26.25 & 4 & 5.41 \\
& c. Culinary art & 4 & 5 & 9 & 12.16 \\
& d. Culinary nutrition & 15 & 18.75 & 21 & 28.38 \\
\hline & Total & 80 & 100 & 74 & 100.00 \\
\hline
\end{tabular}

In this paper, the students who follow the subject are divided into similar number. Shown in Table 4, the research topic of learning media is the highest taken by students for teaching and learning subject, whereas the research topic of culinary nutrition is the highest taken by students for culinary subject.

The research paper titles are mapped based on quality level, research method and main topic. The indicators of research papers' quality are grouped into four categories: (1) duplication titles; (2) replication titles; (3) innovation titles, and (4) creative titles. The results of the document analysis of the research papers' titles submitted by the students are reported in Figure 1. 


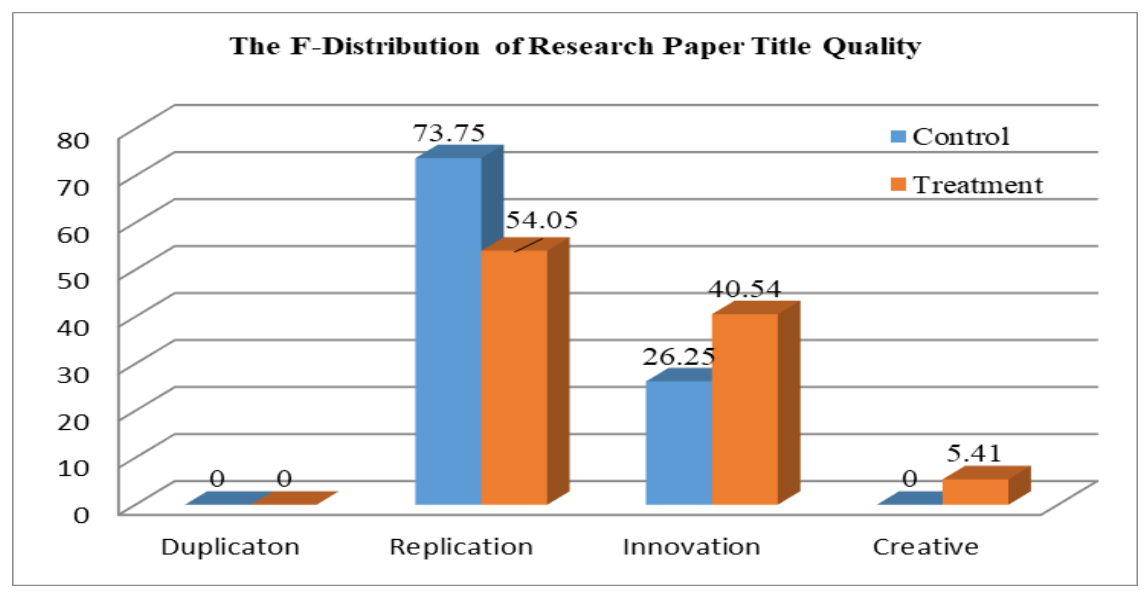

Figure 1

The Frequency Distribution of Research Paper Title Quality

Several indicators of the research papers can be elaborated as follows. Based on the results, there are no duplicative or imitative titles on the student papers both before and after MIRS approach is applied. The replicative titles are the higher one in the student paper. Before the MIRS approach is applied, the title's replication is $73.75 \%$ titles, yet after the MIRS is applied in the classroom, the replication of the title decreases becoming $54.05 \%$. The indicator of students' innovation is low before employing the MIRS method (26.25\%) and increasing significantly after using the MIRS approach $(40.54 \%)$. Another indicator is creative research title. This indicator also increases value after the MIRS is applied on the classroom.

Shown in Figure 1, it can be stated that the MIRS approach is very important to increase the quality of research title. This conditions inspire students either to formulate or to create new idea written on their research titles. The analytical description is obtained by several research methods. They can be shown in Table 5 and are used by the students of Culinary Arts of Vocational Education Program.

Table 5

Types of Research Method Used by Students

\begin{tabular}{clllll}
\hline \multirow{2}{*}{ No. } & \multirow{2}{*}{ Type of Research } & \multicolumn{2}{c}{ The Control Group } & \multicolumn{2}{c}{ The Treatment Group } \\
\cline { 3 - 6 } & f & $\%$ & $\mathrm{f}$ & $\%$ \\
\hline 1. & Explanatory Survey & 28 & 35 & 25 & 33.78 \\
2. & Comparative Survey & 3 & 3.75 & 7 & 9.46 \\
3. & Correlational Survey & 6 & 7.5 & 8 & 10.81 \\
4. & Research \&Development (R\&D) & 12 & 15 & 19 & 25.68 \\
5. & Classroom Action Research & 15 & 18.75 & 1 & 1.35 \\
6. & Quasi-experiment & 3 & 3.75 & 0 & 0.00 \\
7. & Evaluation & 6 & 7.5 & 3 & 4.05 \\
8. & Case Study & 7 & 8.75 & 10 & 13.51 \\
9. & Document Analysis & & & 1 & 1.35 \\
& Total & 80 & 100 & 74 & 100.00 \\
\hline
\end{tabular}


Shown in Table 5, explanatory survey method has the highest value comparing with others and the explanatory survey method becomes the interest method for students. The other methods with also high values are the Research \& Development (R\&D) and the Classroom Action Research. Comparing to the two methods, the students' interest with the R\&D method increases $10.68 \%$ and the students' interest with the Classroom Action Research decreases $17.7 \%$ in 2018. This condition is plausible due to supporting technologies in researching and developing of the learning media growing rapidly, such as internet, android operating systems, and others. Other contrary, the students' interest with the classroom action research decreases significantly because several requirements should be completed by students. Teachers agreement and preparing time in school are become two problems for students who will take this research method.

\section{Research Paper Writing Skill}

To investigate the student witting skill, the oral exams are used to measure writing capability of the research paper. There are four main questions to measure writing capability of the research paper. These four questions are related to (1) the reseach problems, (2) research purposes, (3) method, including research subject, data collection, and data analysis, and (4) research originality. Evaluation of this research paper is very important to examine the quality of the paper, particularly relating with the student honesty. It is due to many plagiarism in the writing subject previously. The score of the writing skill is using standard number $(10-100)$, and then that score is converted into the alphabet sore for A (>85), A- (81-85), B+ (76-80), B (71-75), C+ (66-70), dan C (61-65). The analysis results of the oral examination are presented in Figure 2.

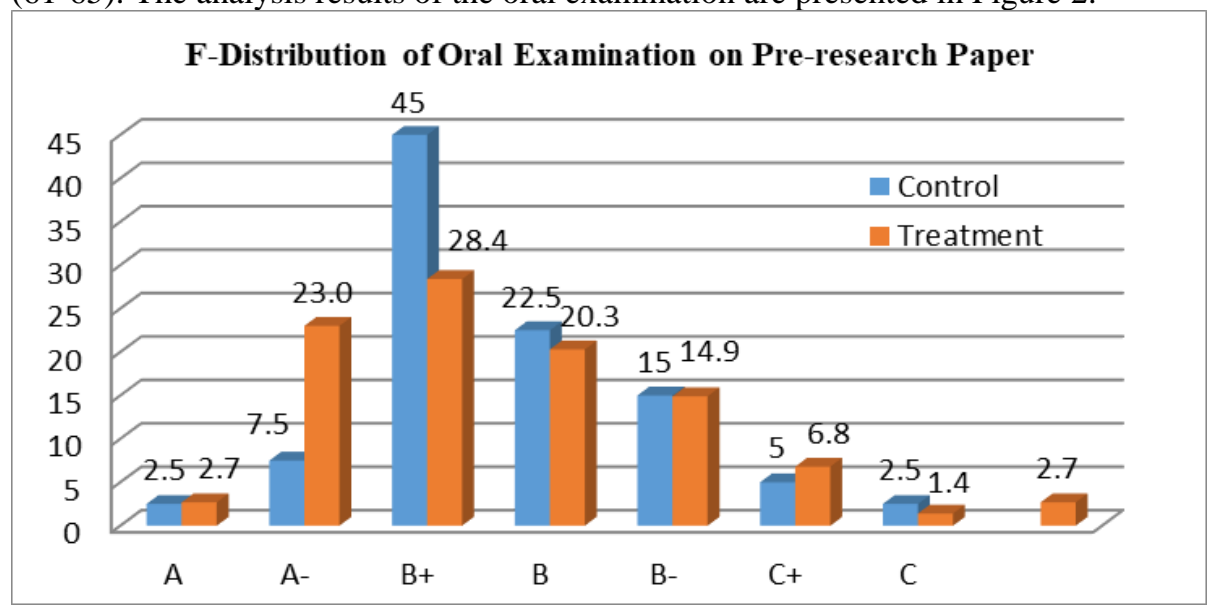

Figure 2

Distribution of Oral Examination on Pre-research Paper

There are $7.5 \%$ of the students in the control group and $23 \%$ of the students in the treatment group who achieved grade A- in the oral examination. After the examination, the students were given a chance to revise and improve their research papers. The 
revision results were tested on research paper presentation. The assessment was done using a performance test by three lecturers.

\section{The Performance in Writing Research Paper}

The writing performance is measured from (1) introduction; (2) literature review; (3) methods; (4) writing organization; and (5) presentation. The result of performance test is presented in Figure 3.

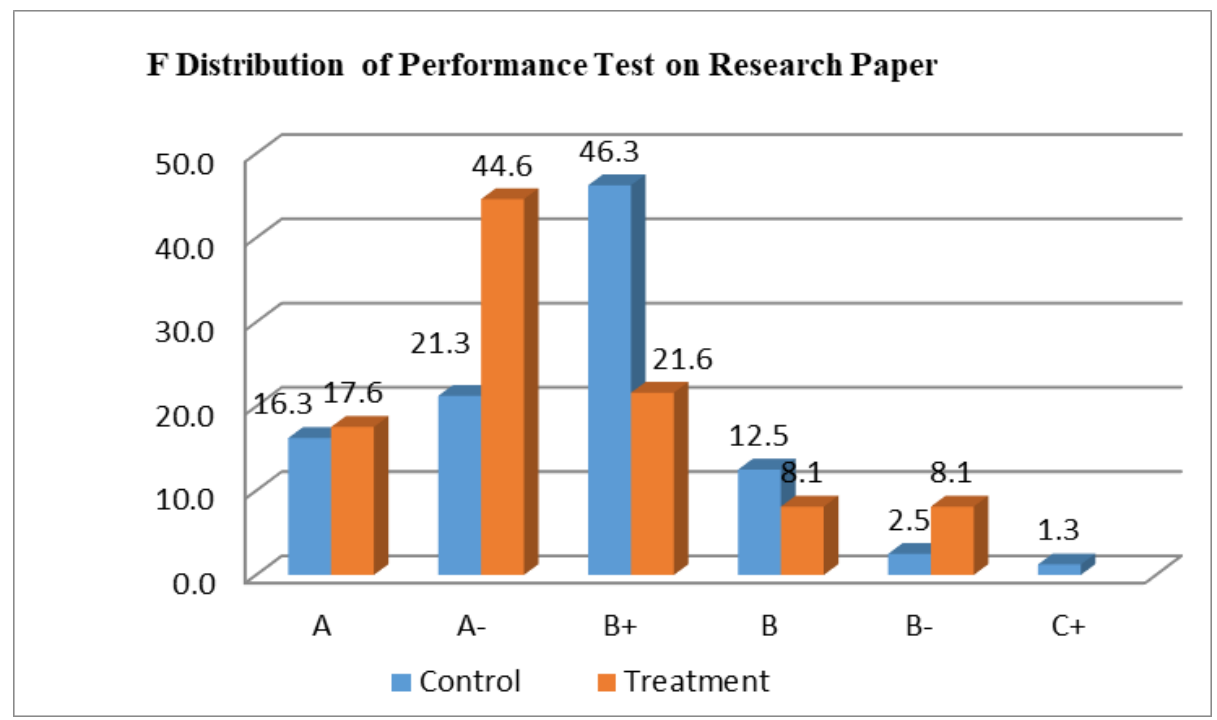

Figure 3

Frequency Distribution of Performance Test on Research Paper

There are $21.25 \%$ of the students in the control group and $44.6 \%$ of the students in the treatment group who achieved grade A-. This result shows that the MIRS approach can improve grades in performance tests on research paper.

\section{The Understanding of Research Methodology}

The students' understanding of theories of research methodology was tested using a paper-and-pencil test in the form of CR. The grade distribution of the paper-and-pencil test is presented in Figure 4. 


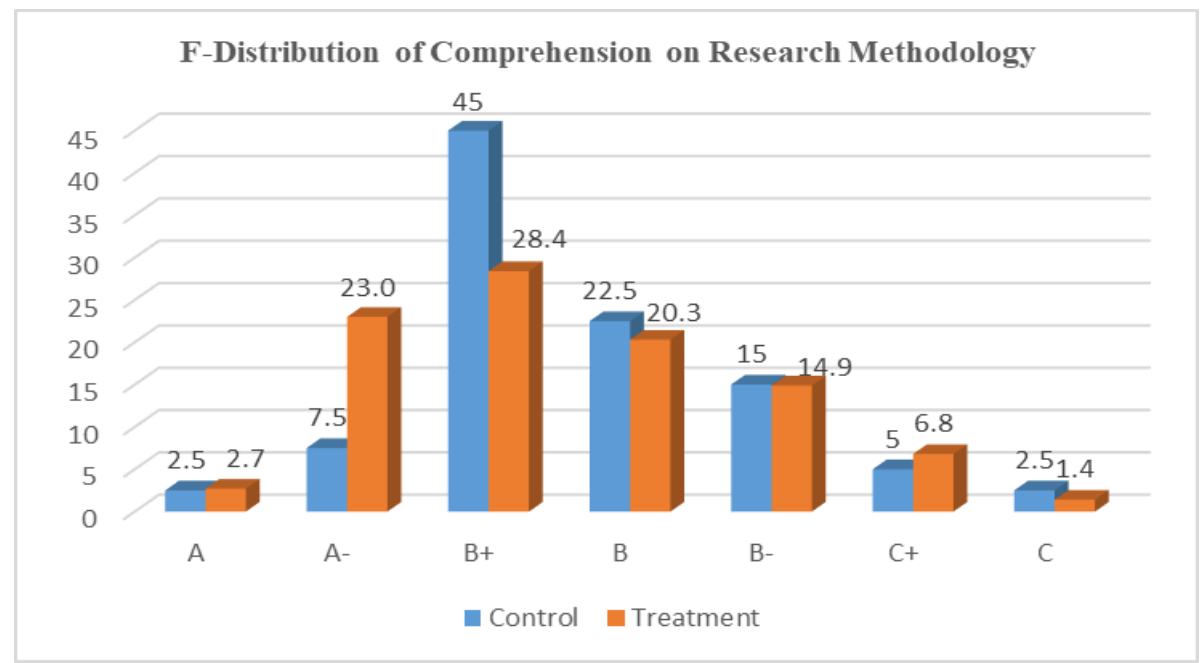

Figure 4

Frequency Distribution of Comprehension on Research Methodology

The result of the CR testing shown in Figure 4. The control group is marked using the blue colour, whereas the treatment group is marked using the orange colour. Based on the Figure 4, the treatment group can be described as follows. The grade " $\mathrm{A}$ " increases $0.2 \%$, the grade "A-" increases $15.5 \%$, the grade "B+" decreases $16.6 \%$, the grade "B" decreases $2.2 \%$, the grade "B-" decreases $0.1 \%$, the grade " $\mathrm{C}+$ " increases $1.8 \%$, and the grade " $\mathrm{C}$ " decreases $1.1 \%$. According to the results, the good grade ("A" and "A-") of the treatment group increases significantly, whereas the low grade of the treatment group decreases except the grade "C+". Due to increasing grade of many students in the treatment group, it can be said that the MIRS approach is an effective method to be applied on the classroom, particularly for the subject of academic writing. The analysis of the results can be detailed in Table 8

Table 8

The Analysis Results of Independent Sample t-test

\begin{tabular}{|c|c|c|c|c|c|c|c|}
\hline \multirow{2}{*}{$\begin{array}{l}\text { Assessment } \\
\text { Results }\end{array}$} & \multirow[t]{2}{*}{ Group } & \multirow[t]{2}{*}{$\mathrm{n}$} & \multirow[t]{2}{*}{ Mean } & \multicolumn{2}{|c|}{$\begin{array}{l}\text { Levene's Test of } \\
\text { Equality of Variances }\end{array}$} & \multicolumn{2}{|c|}{$\begin{array}{l}\text { Independent sample t- } \\
\text { test }\end{array}$} \\
\hline & & & & $\mathrm{t}$ & Sig. & $\mathrm{t}$ & Sig. \\
\hline \multirow{2}{*}{$\begin{array}{l}\text { Oral Examination } \\
\text { on pre-research } \\
\text { paper }\end{array}$} & Control & 80 & 74.95 & 10.095 & .002 & -1.503 & .135 \\
\hline & Treatment & 74 & 76.5811 & & & -1.482 & .141 \\
\hline \multirow{2}{*}{$\begin{array}{l}\text { Paper-and-pencil } \\
\text { test on research } \\
\text { methodology }\end{array}$} & Control & 80 & 63.6125 & 2.363 & .126 & -3.048 & .003 \\
\hline & Treatment & 74 & 68.6216 & & & -3.021 & .003 \\
\hline \multirow[t]{2}{*}{ Performance test } & Control & 80 & 78.7625 & .465 & .496 & -3.19 & .002 \\
\hline & Treatment & 74 & 81.473 & & & -3.184 & .002 \\
\hline
\end{tabular}


The variances of each sample were homogeneous if the significance obtained in Levene's Test >alpha (0.05). The results of the analysis of the independent sample t-test showed that there were significant differences in the paper and pencil test $(p=.003<005)$ and the performance test $(\mathrm{p}=.002<005)$ between the control group and the treatment group. The average value of the oral examination on control group is $74.95<$ experimental group 76.58. The average value of paper-and-pencil test on research methodology for control group is $63.61<$ treatment group 68.62. The average value of the performance test on the control group $78.76<$ treatment group 81.47 . Based on the data analysis, it is shown that the MIRS approach is effective method to improve the students' writing capability of the research paper.

\section{DISCUSSION}

Comparing between two groups holding in the control group (2017) and the treatment group (2018), the replicating titles decreased by $19.7 \%$ while the innovative research papers' titles increased by $14.29 \%$. Once confirmed why many students chose to replicate the titles of the previous research, they said that it was easier for them to conduct research that had been done before. The title of a research paper gives us a glimpse of what method will be used in that particular research. The data on the research method types were analysed using descriptive statistics. Prior to treatment, $19.75 \%$ of the students chose to conduct classroom action research. After the treatment, there were $25.68 \%$ of the students who chose to conduct R\&D. These differences can indicate that there is an increase in the quality of the research paper titles. The students wrote fewer replicating titles and formulated more innovative titles.

Comparing with the previous literature study, Güngör (2018) studied the students' capability of research paper in his classroom. His study explored the distribution of postgraduate theses and articles on ethical leadership in Turkey based on the quantitative approach. His research method employed were surveys and used scales as data collection tools (Güngör, 2018). In this paper, lecturer inspires using R\&D method, so why this method become the highest choosen by students for developing learning digital media. It is in line with the Oleynick studied that the inspiration becomes an imporant role to obtain the creative ideas in title formulating and research strategies (Oleynick, 2014).

The students of the Culinary Arts of Vocational Education Program are prospective teachers and they are expected to maintain high standard of academic ethics. To maintain the ethical code, the research topics are limited into the vocational and culinary subjects. The teaching and learning topic become the highest chosen by students. The results of this study are supported by Marin (Marín, Duart, Galvis, \& Richter, 2018). The main theme is learning and around this topic we can identify different aspects that are relevant in this context, like teaching (overlapping word between learning and education), methods, strategies, course, skills and students. In this period, therefore, learning design and the elements around it are paramount, as can be seen from the literature. 
The authentic assessment can be used to measure the capability comprehensively. In this study, three kinds authentic assessment is used, including oral examination, constructed response, and performance test. Through the oral examination, the students who committed plagiarism could be identified because they would not be able to elaborate satisfactorily the research papers they had written. Average scores of the oral examination, constructed response, and performance test of the treatment group is higher score than the control group. This condition is shown that the MIRS approach can improve the understanding of student research methodology in writing research paper.

The authentic assessment has also been studied by Ismail and Birsen in 2016 who gave authentic tasks and group work to the experimental group. The authentic tasks fulfilled by prospective teachers were analysed in accordance with the authentic assessment approach. Moreover, a comparative analysis of the adjusted post-test results based on the pre-test results of the experimental and control groups indicated a statistically significant positive difference in favour of the experimental group (İsmail \& Birsen, 2016)

Based on the data analysis, the independent sample of t-test shown that there are no different on the oral examination, on the pre-research paper. This is due to the subjective shortcoming of the authentic assessment. However, this drawback would bring impact on the decreasing of the effectiveness at the oral examination. Some the benefit of this method is also explored and bring the changed students behaviour as follows. (1).Plagiarism can be reduced by teacher's reprimand; (2).The students will know the wrong method on writing research paper from the teacher's feedback. Then, students should revise their research paper for obtaining a good quality of it.

\section{CONCLUSION}

The results show that the number of the students who were able to write innovative research papers increased by $14.29 \%$ while the number of those who replicated the existing research papers decreased by $19.7 \%$. As many as $35 \%$ of the control group conducted survey research and the other $18.75 \%$ conducted CAR (classroom action research). As many as $33.78 \%$ of the treatment group conducted survey research while the other $25.68 \%$ conducted R\&D. As many as $26.25 \%$ of the control group conducted research on food marketing while $28.38 \%$ of treatment group conducted research on food nutrition. The control group's average score of research paper writing is lower than that of the experimental group's with 0.63 score difference on oral examination of preproposal and 5.01 score difference on paper and pencil test of research methodology. It can be concluded that MIRS approach is effective for improving writing skill capability.

\section{SUGGESTIONS}

The MIRS has been empirically proved as an effective approach to enhance students' ability in research paper writing. Students who have no writing experience indeed need more motivation to get some writing ideas. In the process of writing paper, students still need teacher's guidance to solve problems that students encountered. This approach requires talented and eminent teachers in helping students. Very good results of 
students' achievement on writing papers will definitely paid teachers' hard work off. Motivation is given by conveying the benefits of completing study on time. The lecturers keep providing inspiration for students until they find problems worthy of research.

\section{REFERENCES}

Akkaya, N. (2014). Elementary teachers' views on the creative writing process: An evaluation. Educational Sciences: Theory and Practice, 14(4), 1499-1504. doi:10.12738/estp.2014.4.1722.

Armstrong, Thomas. (2018) Multiple intelligences in the classroom. Alexandria, VA: Association for Supervision and Curriculum Development,

Bernardo A. S. (2010). Creative ways of teaching research paper writing. ELT World Online.com, 2. Retreived from http://blog.nus.edu.sg/eltwo/2010/03/20

Arlina, A. Z., \& Melor , Y. M. (2015). Potential of mobile learning in teaching of ESL academic writing. English Language Teaching, 8(6), 11-19.

Blythe, H., \& Sweet, C. (2008). The writing community: A new model for the creative writing classroom. Pedagogy 8(2), 305-325.

Caldwell, E. (2011). The teaching of academic writing by practicing esl teachers in an intensive English program. St Paul, Minnesota: Hamline University.

De Larios, J., Manchón, R., \& Murphy, L. (2006). Generating text in native and foreign language writing: A temporal analysis of problem-solving formulation processes. The Modern Language Journal, 90(1), 100-114.

DiMartino, J., \& Castaneda, A. (2007). Assessing applied skills. Educational Leadership, 60(7), 38-42.

Dorothy, S., \& Ferguson, P. B. (2011). Teaching strategies to promote the development of students' learning skills. Retrieved from TDU www.waikato.ac.nz/tdu.

Eby, J. W. (1998). Reflective planning, teaching, and evaluation: K-12. United States of America: Prentice-Hall.

İsmail, 1., \& Birsen, B. (2016). Investigation of the effects of authentic assessment approach on prospective teachers' problem-solving skills. International Education Studies, 9(8), 51-59.

Gardner, H. (2011). Frames of mind: The theory of multiple intelligences. New York: Basic Books.

Güngör, K. S. (2018). Content analysis of theses and articles on ethical leadership. International Journal of Instruction, 11(4), 901-920. doi:10.12973/Iji.2018.11457a.

Lengeling, M., \& Malarcher, C. (1997). Index cards: A natural resource for teachers. Forum, 35(4). Retrieved from 
https://www.researchgate.net/publication/265072745_Index_Cards_A_Natural_Resourc e_for_Teachers.

Marín, V. I., Duart, J. M., Galvis, A. H., \& Richter, O. Z. (2018). Thematic analysis of the international journal of educational technology in higher education (ETHE) between 2004 and 2017. International Journal of Educational Technology in Higher Education, 15, 8. doi: 10.1186/s41239-018-0089-y.

McNiff, S. (1998). Trust the process: An artist's guide to letting go. Boston: M.A. Shambhala.

Negari, G. M. (2011, 9). A study on strategy instruction and EFL learners writing skill. International Journal of English Linguistics, 1(2), 299- 307.

Neuman, W. L. (2011). Social research methods: Qualitative and quantitative approaches. Edinburgh Gate Harlow: Pearson.

Olfos, R., \& Zulantay, H. (2007). Reliability and validity of authentic assessment in a web based course. Educational Technology \& Society, 10(4), 156-173.

Oleynick, V. C., et all. (2014). The scientific study of inspiration in the creative process: challenges and opportunities. Williamsburg VA, USA: Department of Psychology, College of William and Mary.

Payne (2012). Development of the academic writing motivation questionnaire. Georgia: The University of Georgia

Smedt, F. D., \& Keer, H. V. (2018.). An analytic description of an instructional writing program combining explicit writing instruction and peer-assisted writing. Journal Writing Research, 10(2), 225-277. doi: 10.17239/jowr-2018. 10. 01. 04.

Sturm, J. M., \& Rankin, J. L. (2002, 5). Effects of hand-drawn and computer generated concept mapping on the expository writing of middle school students with learning disabilities. Learning Disabilities Research \& Practice, 17, 124-139. doi:10.1111/15405826.00039 .

Tombari, M. L., \& Borich, G. D. (1999). Authentic assessment in the classroom; New Jersey: Prentice Hall.

Winterson, J. (2012). Teaching creative writing. Retrieved from www.guardian.co.uk/books/2012/may/18/jeanette-winterson-teaching-creative-writing. 